University for Business and Technology in Kosovo

UBT Knowledge Center

UBT International Conference

2018 UBT International Conference

Oct 27th, 1:30 PM - 3:00 PM

\title{
Water Losses Management in Mitrovica region
}

\author{
Faruk Hajrizi \\ University for Business and Technology, faruk.hajrizi@ubt-uni.net \\ Izet Ibrahimi \\ University for Business and Technology, izet.ibrahimi@ubt-uni.net
}

Follow this and additional works at: https://knowledgecenter.ubt-uni.net/conference

Part of the Civil and Environmental Engineering Commons

\section{Recommended Citation}

Hajrizi, Faruk and Ibrahimi, Izet, "Water Losses Management in Mitrovica region" (2018). UBT International Conference. 76.

https://knowledgecenter.ubt-uni.net/conference/2018/all-events/76

This Event is brought to you for free and open access by the Publication and Journals at UBT Knowledge Center. It has been accepted for inclusion in UBT International Conference by an authorized administrator of UBT Knowledge Center. For more information, please contact knowledge.center@ubt-uni.net. 


\title{
Water Losses Management in Mitrovica region
}

\author{
Faruk Hajrizi, Izet Ibrahimi \\ UBT - Higher Education Institution, Lagjja Kalabria, 10000 p.n., Prishtina, Kosovo \\ faruk.hajrizi@ubt-uni.net,
}

\begin{abstract}
The purpose of this paper is to reduce water losses by presenting the unregistered customer situation, the number and where they are mainly distributed. In the context of analyzing the commercial and technical losses of the water in the Mitrovica region, a project for the reduction of water losses was devised. Financial support for project realization is ensured by the project funded by the Luxembourg Government for the Regional and Water Company Mitrovica, which has enabled to implement a project with significant activities to reduce water losses. During the project development we undertook site visits, field work evaluations were conducted and frequent water supply meetings were held in order to achieve the goals mentioned in the project for the start-up phase. The study also presents the findings of site visits, illegal connection in water network, staff assessment regarding Information Management and GIS
\end{abstract}

Keywords: Water losses, illegal connection, GIS, Information Management

\section{Introduction}

Drinking water loss or Non-Revenue Water (NRW) threatens the financial viability of water utilities and sustainable natural water resource management. To most water utilities, the level of NRW is a key performance indicator of efficiency. However, most utilities tend to underestimate NRW because of institutional and political pressures, as well as a lack of knowledge to properly determine the NRW level.

Water Loss or Non-Revenue Water (NRW) represents inefficiency in water delivery and measurement operations in transmission and distribution networks and, for some systems, can amount to a sizeable proportion of total water production. The Water Losses for a whole system or for a partial system are calculated as the difference of Systems lnput Volume and Authorized Consumption. The Water Losses consist of Real and Apparent Losses:

- Real Losses are physical losses of leaks, bursts and overflows from the pressurized system, up to the point of metering on the service connections.

- Apparent Losses consist of all types of meter inaccuracies (input, output, and customer meters) and unauthorised consumption (theft and illegal use). Also termed as commercial losses.

- The work involved two phases, in the first phase included the review and updating of the inventory of technical assets in the GIS system, followed by the second phase with data collection in the Mitrovica region based on the objective of the work. The pilot's aim was to identify:

- Time required to obtain data on customers and the water supply network;

- $\quad$ Time needed to translate this data into a spatial data system (GIS); 
- Obstacles that would pose a challenge when extending data beyond the pilot zone and recommend modifications to data capture methods that would put time efficiency savings.

Any new problem, water connection, or defects identified in the water supply network by a field team is reported by a collector of reports or from a client / client to the 'damage office'. Submitting a written complaint shall be forwarded to the Planning and Development Department for review and decision on the action required.

Problems identified in this area have been addressed to the department and are reviewed / approved for necessary actions by the Head of Department. After fixing the problem, the maintenance and repair team reports in writing and then decides whether to close the case or be followed up with further action.

Regarding the communication and interaction between staff in terms of information management and GIS, the project has found that there is room for improvement. Most of the interaction is adhoc during office planning and design processes or during site visits. The department's work procedures are set out in the guidelines provided by WWRO and should be fully and continuously observed and followed. Staff also join in some cases to convert the data or to report, record or input the data. There is a tendency to keep records and documents only on hard-copy and archiving without further distribution.

In summary, all affairs and problems identified on the ground are recorded only in printed copies and are not recorded in electronic format and are specifically not integrated within the GIS.

\section{Methods}

This round of checking takes place about two weeks after the files have been sent to the Editorial by the Contact Volume Editor, i.e. roughly seven weeks before the start of the conference for conference proceedings, or seven weeks before the volume leaves the printer's, for postproceedings. If SPS does not receive a reply from a particular contact author, within the timeframe given, then it is presumed that the author has found no errors in the paper. The tight publication schedule of LNCS does not allow SPS to send reminders or search for alternative email addresses on the Internet.

In some cases, it is the Contact Volume Editor that checks all the pdfs. In such cases, the authors are not involved in the checking phase.

\section{Block division size}

The prewar coordinate system used in former Yugoslavia (FryRef30) was in Gauss Kruger projection; following separation each republic adopted its own unique local projection. For Kosovo this is called KOSOVAREF01 (KosREF 01). Surveying experts state that this results in shifts in different proportion in the different areas. FryRef30 had the rather cumbersome block division of $500 \times 750$ meters, whilst the current block division is $4000 \times 4000$ meters and has smaller divisions of $1000 \times 1000$ meters depending on detail and scale of use. The official parameters of KosREF01 are as follows:

For the current project a block division of 500×500 meters, based on KosREF01, was used. This block division covers Kosovo and it is compatible with that used by other regional water companies in Kosovo. The official block division of $4000 \times 4000$ meters from the Kosovo Cadastral Agency (KCA), is shown below for Mitrovica region and its component municipalities.

From the sub-divided grid in every 1000 x 1000 meters it is presented the RWCM water network infrastructure in large scale for viewing purposes. For the block mapping purposes, the block division for MRWC based on the KCA grid are subdivided again into $500 \times 500 \mathrm{~m}$. This subdivision is done for better management of the staff in the field and for data collection. 
This print screen of the map shows it can fit in current 24" plotter RWCM possess. This map is used for data collection and it can fit 2 maps (cell size 500x500 meters) with paper dimension of $(0.61 \times 1.15)$ meters in the scale $1: 1000$. The digitizing of air/space borne imagery has been organized emanating outwards from the center of the town or based on the pilot area. During component 2 the priority was to add a vector point to locate buildings with ortho-photos and to attribute these. New buildings were digitized as polygons and interlinked with consumer points. Digitizing roads and other information from airborne imagery is too time consuming at this stage.

The GeoEye SPOT satellite imagery acquired on 11/21/2011 can only be used for the internal work of RWCM. The satellite image received was converted to ECW format for fast screen processing without degrading its resolution.

\section{Data validation}

Field teams are required to complete the relevant form which is linked to the paper map via a unique reference number. The interviewer/surveyor adds the cadastral zone, neighborhood, number of the map on the paper form and then signs and dates each record. Data entry staff subsequently sign and date when data have been digitized and entered into the GIS. The GIS officer validates data and has the responsibility for these.

For reference purposes all paper maps and forms should be saved in a secure location. The volume of data to be validated is based on the block mapping sheets finished. Only those maps that are fully interviewed in the field and entered into GIS system form the RWCM employee. The team compares the data from the paper forms for any misinformation

The map below shows a print screen of the paper map from the field with hand written unique numbers for each house hold identified by the bill collectors.

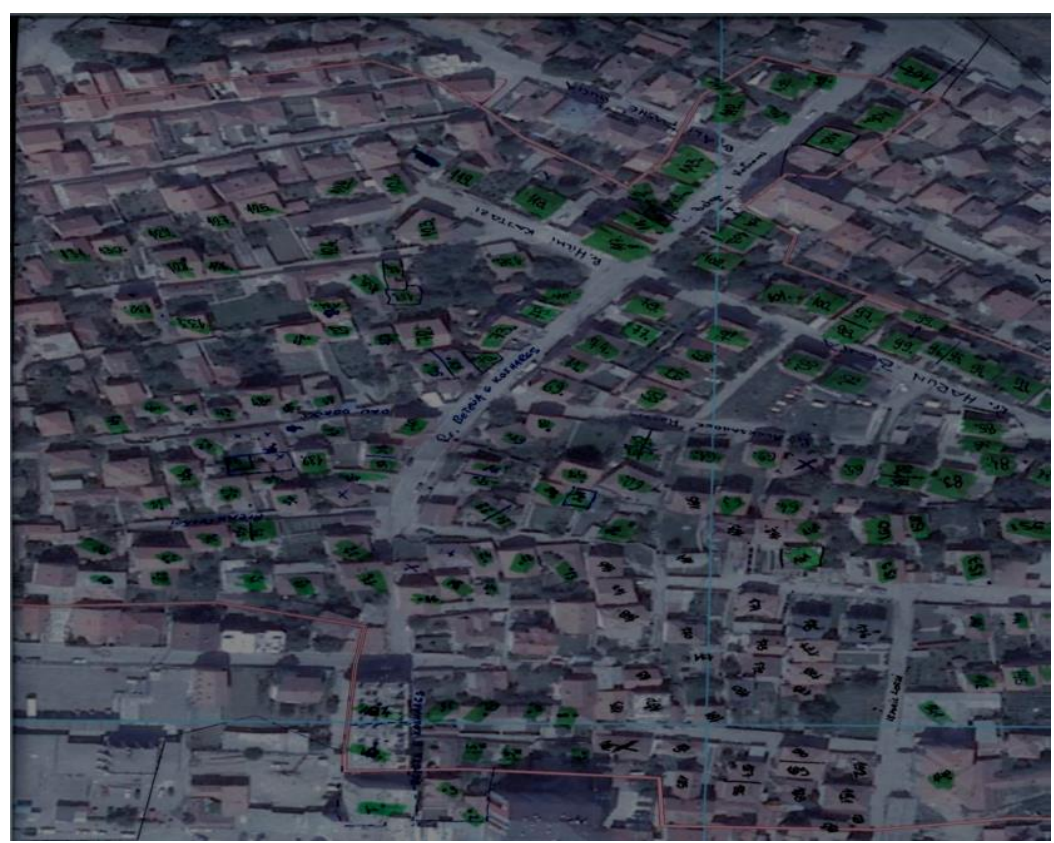

Figure 1. Print screen of paper maps with information from the field 


\section{Design of recording procedure of the validated data}

The registration procedure for the exercise of map blocking is defined in the official written communication between the officials of RWCM; where it is understood that the data obtained on the ground should be certified by the specialized IT team. Each field team is obligated to present to the Planning department a fully annotated printed map with information for each house together with all related forms. These data are digitized and attributed; for each form there is an obligation to write the name of the data entry operator and the date when the data were electronically entered into GIS system. The block paper maps together with the related forms and the vector data and then forwarded for final approval. As part of the quality control protocol, IT team runs queries to check for duplicates customer names, billing numbers, water meters and other anomalies.

The method of establishing location in the field switched from GPS to paper maps. The GPS suffers from poor locational accuracy when close buildings and particularly so in urban areas, which would lead to unavoidable manual downstream data cleaning. Hence the use of paper maps is preferred for this activity.

\section{Briefing survey teams form filling}

Each field team was briefed on their role and the standard of work expected of them. Briefings addressed the method of locating houses using paper maps, the structure of the data recording form and how to link map reference numbers to the form. Each customer has the coordinates and billing numbers given from the billing officer from his sheets for each area, those who found new RWCM customer and doesn't have billing number they are forced to write as unregistered for further investigation from RWCM.

IT team conducted a survey in one pilot zone for 5 days with one RWCM field team. In this pilot zone it was engaged bill collector who he lead us to every costumers and in the mean time we designed the form what information at this stage we can collect in order the process to go faster and qualitative. In this pilot zone we found most of the issues that each team can face in the field and how to solve. During the pilot zone with one team we calculated roughly one team to collect at least 50 costumers per day during the working hours In the table showed below is the actual volume of the data collected per map sheet.

Monthly Progress Report of cartographic block has been issued with data records collected on the ground and placed in GIS. Only data that has been validated by the IT team have been shown to PCUs on thematic maps. The following map shows dates embedded in GIS after verification. 


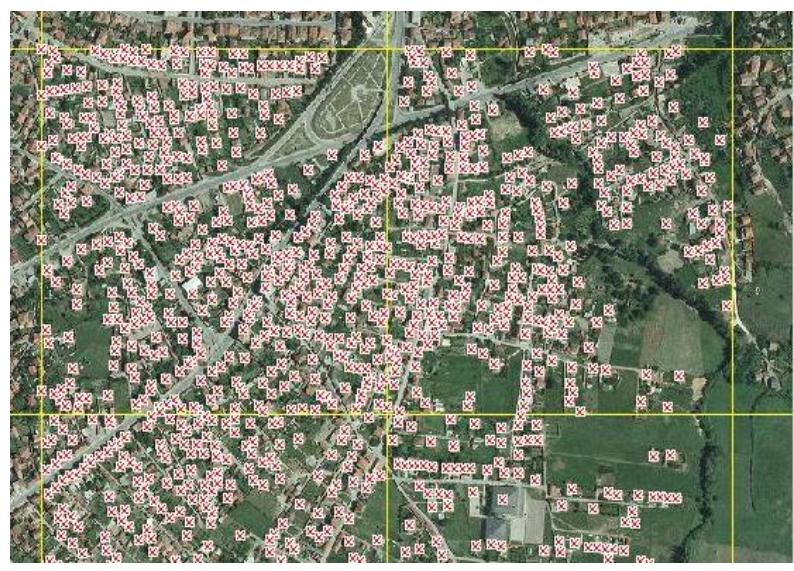

Figure 2. Blok haprography

Field teams that are set in cooperation with the Technical Director RWC Mitrovica will be: for Mitrovica 3 teams, $1+1$ team for Vushtrri and 1 team for Skenderaj. In these teams every bill collector for their dedicated regions will be included in collecting data due to accelerating the works as well the population in each region recognize their bill collector. This issue we had for pilot zone, people in the street, literally they stopped and asked us why and what we are doing in their neighborhoods before they saw that we are together with bill collector and we came to work for RWCM so the explanation is easy to them because bill collector talks with them.

Bill Collectors in their regions will lead these teams and at the same time will perform their daily duties without obstruction. Teams will be in every place where the bill collector has priority for delivery of invoices as well as for collection of payments (money collecting).

All necessary maps for field will be printed in scale 1: 1000, year 2009 with ortho-photo background

and will deliver the to all teams relevant forms approved earlier.

During the field survey it was requested for Vushtrri Municipality to create additional team (1 +1 ) without any extra payment from the dedicated budget for this project. Below is the simple table of calculation for total number of costumers

\section{Progress of the block mapping exercise}

Despite initial challenges relating to the willingness of RWCM staff to perform to the level to which they were trained, progress of the exercise to date has been good. This is attributed in no small part to the support of RWCM management, CEO and Technical Director, who facilitated the exercise by providing necessary resources.

\section{Supervision of progress and quality of the digitizing}

Data from the field will be entered into the GIS format with already created layers from pilot area and this layer was approved in the meeting with RWCM higher management. Responsibility for data entering will have department of planning, validation of data into GIS system for all costumers it is IT team responsibility until the project is finished. RWCM Staff who will digitize/enter data collected from the field 


\section{Field data collection supervision}

The list of surveyors was rarely changed. Changes were made based on personal reasons from the actual surveyor rather than as a result of poor performance. The reasons for changing the field staf were age, health conditions or not feeling comfortable to work in the field. All the changes to the field teams were approved by RWCM management. Field supervision by IT team was based on monitoring teams two days per week, with most these visits in Mitrovica Municipality. The IT team was divided into three sub-teams, each IT teams with responsibility for a particular municipality. In Vushtrri Municipality was requested to create an additional team because of the volume of data and our supervision was done on the site without previous announcement because of the validation process of the data into GIS. For the Municipality of Skenderaj only first few weeks supervised the only team and later there was no supervision because of the other priorities set up from the local management specifically the Skenderaj Operation manager.

Each team went announced to each Municiaplity and double check RWCM teams how they conduct the work from the training they got previously, are they performing exactly, what are the obstacles they facing in the field any needs and solving issues on the site.

\section{Results and Discussion}

From the data obtained in the field during this research and their placement in the GIS we noticed quite large differences in the number of consumers. The figure clearly shows the distinction between registered customers and unregistered customers in the billing system, which represents a difference somewhere around $22.5 \%$. The figure also shows the ratio between water losses before and after the completion of this survey, which reaches the same value in percentages.

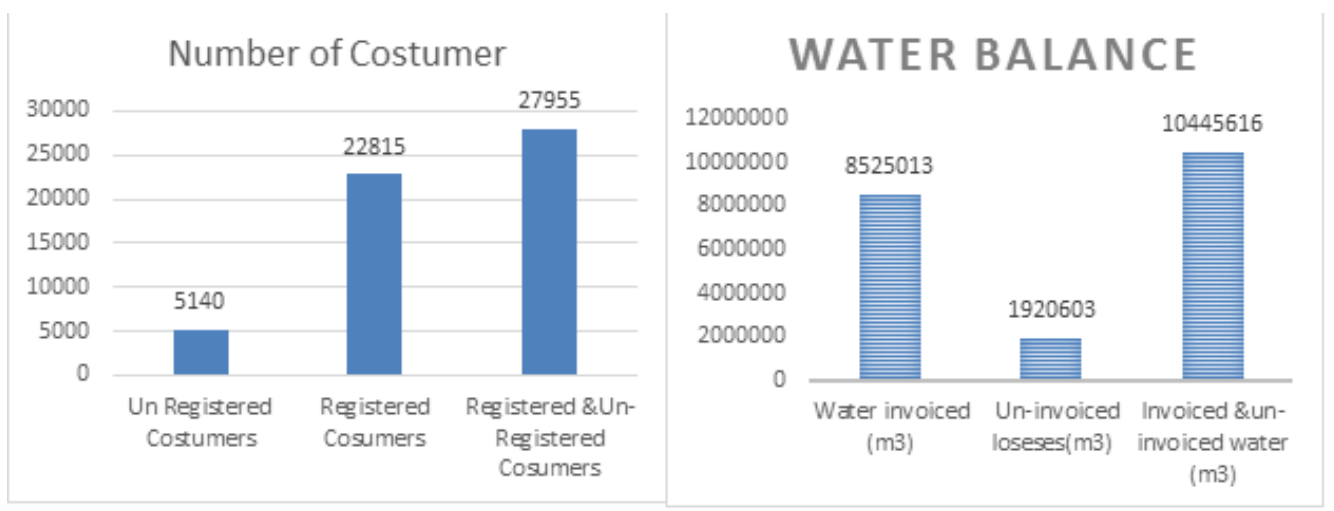

Figure 3. Relationship between customer number and water balance

Në aspektin finaciar hulumtimi ka nxjer në pa humbjem vjetor mjaft të mëdha, vlera e tyre arrin vleren prej gjysëm miloni për një vit siq është dhëne në figuren 4. Nëse merren parasysh të humbjen e grumbullara për vitet të tëra atëhere vlera e ketij punimi shkencor është mjaftë e lartë. 


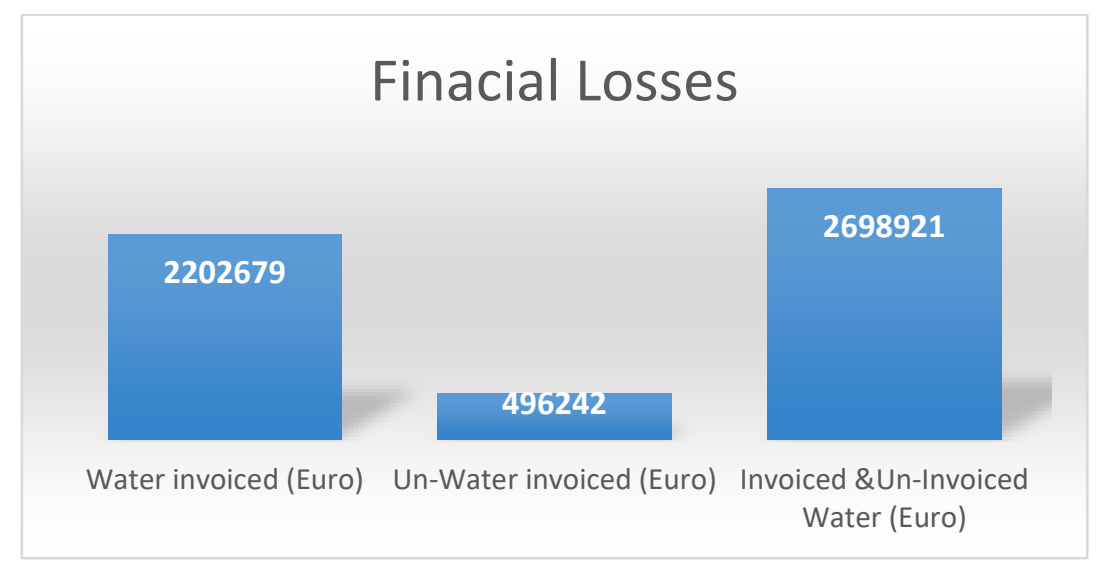

Figure 4. Financial losses

This spatial analysis may be used as a starting point for other analysis in the future that will help in putting priorities and act accordingly. It has been done for the Region of Mitrovica, to give us a brief overview regarding the issue of unregistered customers that the Company should deal with in the future and hopefully resolve it in the best way possible, for the customer and the Company itself.

\section{REFERENCES}

1. Farley, M (2008) The Manager's Non-Revenue Water Handbook - A Guide to Understanding Water Losses (2)

2. Lambert A, Hirner W. Losses from water supply system: Standard Terminology and recommended performance measures. 2002;32(1):29-38.

3. Richard Pilcher, Altan Dizdar, Selcuk Toprak, Elmo De Angelis, Abdullah Cem Koc, Cuneyt Dilsiz, Kylene De Angelis, Fatih Dikbas, Mahmut Firat, Ulker Guner Bacanli (2008), PROWAT Basic Water Loss Book. 